\title{
REAKSI PASAR MODAL INDONESIA TERHADAP PEMILIHAN PRESIDEN AMERIKA SERIKAT TAHUN 2020
}

\author{
Jidan Apriyanto ${ }^{1}$, Sri Mulyantini ${ }^{2}$, Nurmatias ${ }^{3}$ \\ 1,2,3 Univesitas Pembangunan Nasional Veteran Jakarta, Jakarta, Indonesia \\ Email korespondensi: ${ }^{1}$ jidanapriyanto@upnvj.ac.id
}

\begin{abstract}
ABSTRAK
Tujuan penelitian ini adalah untuk mengetahui reaksi pasar modal Indonesia ketika terjadi peristiwa politik di Internasional. Perusahaan LQ45 periode Agustus 2020-Januari 2021 dipilih sebagai populasi dan sampel dengan menggunakan metode sample jenuh. Teknik single index model digunakan untuk mencari abnormal return. Periode jendela peristiwa lima belas hari, dan tiga puluh hari periode estimasi dengan teknik analisis data gabungan antara One Sample t-test, One Sample Wilcoxon Signed Rank Test, dan Paired Sample t-test. Hasil analisis menunjukan tidak terdapat imbal hasil tak normal yang signifikan di sekitar periode peristiwa, tetapi kondisi abnormal return sebelum dan sesudah peristiwa pilpres AS 2020 mengalami perbedaan yang signifikan. Terdapat trading volume activity yang signifikan selama lima belas hari di sekitar periode peristiwa tersebut. Terjadi reaksi di LQ45 pada abnormal return tetapi tidak signifikan dengan trading volume activity yang signifikan. Dengan mempertimbangkan kedua hal tersebut pada saat terjadinya suatu peristiwa politik, investor dapat mengambil sikap dengan menggunakan analisis mendalam tentang kecenderungan return yang terdapat di sebuah pasar modal.
\end{abstract}

Kata Kunci: abnormal return; Indeks LQ45; studi peristiwa; trading volume activity

ABSTRACT

The purpose of this research is to determine the reaction of the Indonesian capital market when international political events occur. LQ45 companies for the period August 2020-January 2021 were selected as the population and sample, using the saturated sample method. With the single index model technique to find the abnormal return. The event window period is fifteen days, and the estimation period is thirty days with a combined data analysis technique between One Sample t-test, one sample Wilcoxon Signed Rank Test and Paired Sample t-test. The results of the analysis showed that there were no significant abnormal returns around the event period, but the abnormal return conditions before and after the 2020 US presidential election experienced significant differences. There was significant trading volume activity for fifteen days around the event period. There was a reaction in LQ45 on abnormal returns but not significant with significant trading volume activity. By considering these two things when a political event occurs, investors can take a stand by using an in-depth analysis of the trend of returns in a capital market.

Keywords: abnormal return; event study; LQ45 Index; trading volume activity

KETERANGAN ARTIKEL

Riwayat Artikel: diterima: 06 Agustus 2021; direvisi: 17 Desember 2021; disetujui: 24 Desember 2021

Klasifikasi JEL: G14

Cara mensitasi: Apriyanto, J., Mulyantini, S., \& Nurmantias. (2021). Reaksi Pasar Modal Indonesia Terhadap Pemilihan Presiden Amerika Serikat Tahun 2020. JIMFE (Jurnal Ilmiah Manajemen Fakultas Ekonomi), 7(2), 189-202. https://doi.org/10.34203/jimfe.v7i2.3714 


\section{PENDAHULUAN}

Pasar modal merupakan satu dari sekian instrument keuangan erat kaitannya dengan perekonomian suatu negara. Dalam Undang-Undang Republik Indonesia Nomor 8 Tahun 1995 dijelaskan bahwa pasar modal memiliki peran yang cukup strategis bagi dunia usaha dan sebagai media investasi bagi masyarakat. Sebagai salah satu instrument ekonomi, pasar modal tak pernah lepas dari hantaman atas peristiwa yang tak terkira banyaknya yang berada di sekitar lingkungannya, peristiwa-peristiwa ekonomi seringkali mengganggu pergerakan arah pasar modal untuk menanjak atau menurun. Bahkan isu-isu non-ekonomi pun kerapkali membuat investor harus sigap menyikapi permasalahan yang ada dan dituangkan dalam analisa nya bagi pasar modal untuk kedepannya. Salah satu jenis penelitian tentang peristiwa non ekonomi yang telah mempengaruhi pasar modal Indonesia dikenal dengan istilah studi peristiwa (event study), salah satu nya adalah peristiwa politik. Beberapa kemungkinan sering digunakan dalam menilai pasar merespons suatu peristiwa dengan pendekatan volume pergadangan saham dan return saham.

Abnormal return seringkali dijadikan sebagai salah satu indikator untuk mengukur suatu reaksi atas perisitiwa atau kejadian tertentu (Pratama, 2017). Return saham menurut Jogiyanto (2008) menyatakan bahwa return dapat berupa return relasisasi yang sudah terjadi atau return ekspektasi yang diharapkan dimassa datang. Banyak penelitian mengenai event study yang menggunakan pendekatan return saham seperti Onder \& Mugan (2006), Rahayu (2007), Yulita (2018), Murdifi dkk. (2018), dan Katti (2018), Nailiu (2014), Pratama, dkk (2015), dan Cahyani (2017). Penelitian event study untuk menilai apakah suatu peristiwa tertentu mengakibatkan terjadinya abnormal return pada sebuah pasar modal.

Peristiwa politik merupakan peristiwa yang dinamis bagi pasar modal, investor akan selalu merespons kondisi politik suatu negara dengan pergerakan arah bursa, dan hal ini bisa menjadi positif maupun negative. Ekspektasi investor terhadap pasar dapat berubah arahnya karena psikologis dari investor itu sendiri, yakni dengan bagaimana seorang investor merespons segala informasi yang terjadi disekitar lingkungan pasar modal. Dimana ketika suatu peristiwa direspons sebagai informasi yang bersifat good news maka abnormal return yang terjadi merupakan kenaikan dari returnnya, sebaliknya apabila peristiwa direspons sebagai informasi negatif atau bad news maka abnormal return yang terjadi meruoakan penurunan dari return.

Kondisi empiris yang tertuang dalam penelitian Ahmed dkk. (2020) menyatakan kemenangan Trump pada pemilu AS 2016 memberikan efek kurang begitu baik pada bursa Amerika Serikat. Silaban \& Sedana (2018) serta Kusumayanti \& Suarjaya (2018) sepakat menyatakan bahwa kemenangan Donald Trump dalam pemilihan presiden Amerika Serika tahun 2016 memberikan sentimen yang cukup signifikan pada pasar modal Indonesia pada sekitar periode peristiwa. Di pasar modal Indonesia terdapat suatu indeks yang bisa menjadi tolok ukur dari pergerakan arah bursa, yakni LQ45 yang merupakan 45 saham emiten yang terpilih sebagai saham-saham paling likuid. Indeks LQ45 seringkali digunakan peneliti untuk melakukan berbagai kajian tentang pasar modal terutama untuk mengkaji reaksi pasar modal terhadap suatu peristiwa seperti Nailiu (2014), Trisnawati (2011), dan Murdifi dkk. (2018). Hal ini karena LQ45 merupakan kumpulan dari saham yang paling aktif diperjualbelikan di Bursa Efek Indonesia, di dalam indeks LQ45 terdapat emiten dari berbagai sektor yang terdaftar di Bursa Efek Indonesia (BEI) dan bisa dinilai cukup mewakili dari berbagai berbagai emiten yang terdaftar di sana.

Sehubungan dengan peristiwa politik di AS terkait terpilinnya Joe Biden, diprediksi akan berdampak positif pada LQ45 yang terdiri dari saham seperti sektor komoditas, tekstil, dan perbankan yang dengan terpilihnya Joe Biden pada bursa saham terutama saham yang disebutkan sebelumnya. Joe Biden akan memberikan stimulus fiskal dalam jumlah besar, akan semakin banyak dollar AS yang beredar di perekonomian, sehingga menurut teori greenback akan melemah (Sidik, 2020). Pelemahan dollar AS menjadikan salah satu komoditas yang ada di LQ45 diuntungkan, seperti ANTM dan MDKA yang merupakan emiten komoditas emas yang dihitung dengan acuan dollar AS. Pertarungan demokrasi 
yang terjadi pada 2020 lalu di mana kandidat petahana yakni Donald Trump ditantang oleh Joe Biden menjadi ajang yang menarik untuk disimak. Donald Trump dikenal sebagai pemimpin yang memiliki kontroversi yang cukup besar ketika memimpin AS sejak tahun 2016 lalu.

Indeks Harga Saham Gabungan (IHSG) dan LQ45 mengalami penguatan cukup signifikan dan mengalami reversal yang dimulai pada tanggal 4 November 2020 dengan harga penutupan Rp5.105,20 dan terus bertahan pada bullish trend. Pada hari pengumuman kemenangan Joe Biden, yakni 9 November 2020, baik IHSG, LQ45, maupun Indeks Dow Jones mengalami penguatan kembali dengan cukup signifikan. Untuk IHSG sendiri menutup perdagangan pada tanggal 9 November 2020 di angka Rp5.356,00 dan sempat menyentuh harga tertinggi sebesar Rp5.395,71 pada hari perdagangan yang sama. Penguatan yang sama pun dialami oleh LQ45 berada di posisi Rp781,13 pada penutupan perdagangan 4 November 2020, dan mengalami penguatan pada tanggal 9 November 2020 atau pada saat pengumuman kemenangan Joe Biden sebesar Rp840,51. Penguatan terus berlanjut hingga penutupan perdagangan tanggal 11 November 2020 sebesar Rp880,02. Walaupun sempat terjadi koreksi, IHSG tetap berada pada bullish trend selama seminggu pasca peristiwa pengumuman kemengangan Joe Biden. Indeks Dow Jones (DJI) justru melahap informasi sejak tanggal 30 Oktober 2020 sudah ada tanda-tanda memantul ke atas. DJI memasuki tren bullish ketika sebelumnya berada pada bearish trend pada tanggal 23 Oktober 2020 sampai tanggal 30 Oktober 2020 dan kemudian mengalami reversal cukup signifikan pada 4 hari bursa setelahnya. Pada saat peristiwa pengumuman Joe Biden sebagai pemenang dari perebutan kursi panas kepemimpinan pada tanggal 9 November 2020, DJI melanjutkan trennya dengan sangat signifikan, yang mana mengalami kenaikan dari harga penutupan Rp26.501,60 pada tanggal 30 Oktober 2020 menuju harga penutupan Rp 9.157,97 pada tanggal 9 November 2020. Indeks tersebut terus mengalami kenaikan selama 7 hari bursa kedepannya sejak tanggal pengumuman peristiwa tersebut (Indonesia Stock Exhange, 2020).

Reaksi kedua bursa, Bursa Saham Amerika Serikat dan Indonesia, hampir mirip pola pembentukan trennya, di mana hari sebelum pengumuman Joe Biden sebagai Presiden AS 2020 terpilih hingga hari peristiwa mengalami tren yang sama, yakni bullish trend. Hal ini menunjukkan bahwa kejadian tersebut memiliki kandungan informasi yang positif bagi bursa dan menarik untuk diuji dan dianalisis kandungan informasi yang ada.

Selain abnormal return yang terjadi, terdapat pula adanya peningkatan trading volume activity disekitar periode peristiwa, terlihat pada gambar di bawah bahwa ada peningkatan yang cukup tajam di sekitar hari pengumuman kemengangan Joe Biden pada pasar modal Indonesia yakni IHSG. Hal ini terjadi karena pasar berekasi cepat dengan bertransaksi pada pasar modal memanfaatkan momentum yang ada. Selain IHSG, LQ45 memiliki grafik aktivitas yang serupa dengan IHSG pula. Hal ini menunjukkan adanya aktivitas yang besar terjadi pada sekitar periode peristiwa terhadap saham yang terdaftar pada Indeks LQ45. Serupa dengan IHSG saham yang berekasi pada indeks LQ45 memanfaatkan momentum untuk menggali abnormal return yang terjadi di sekitar periode peristiwa. 


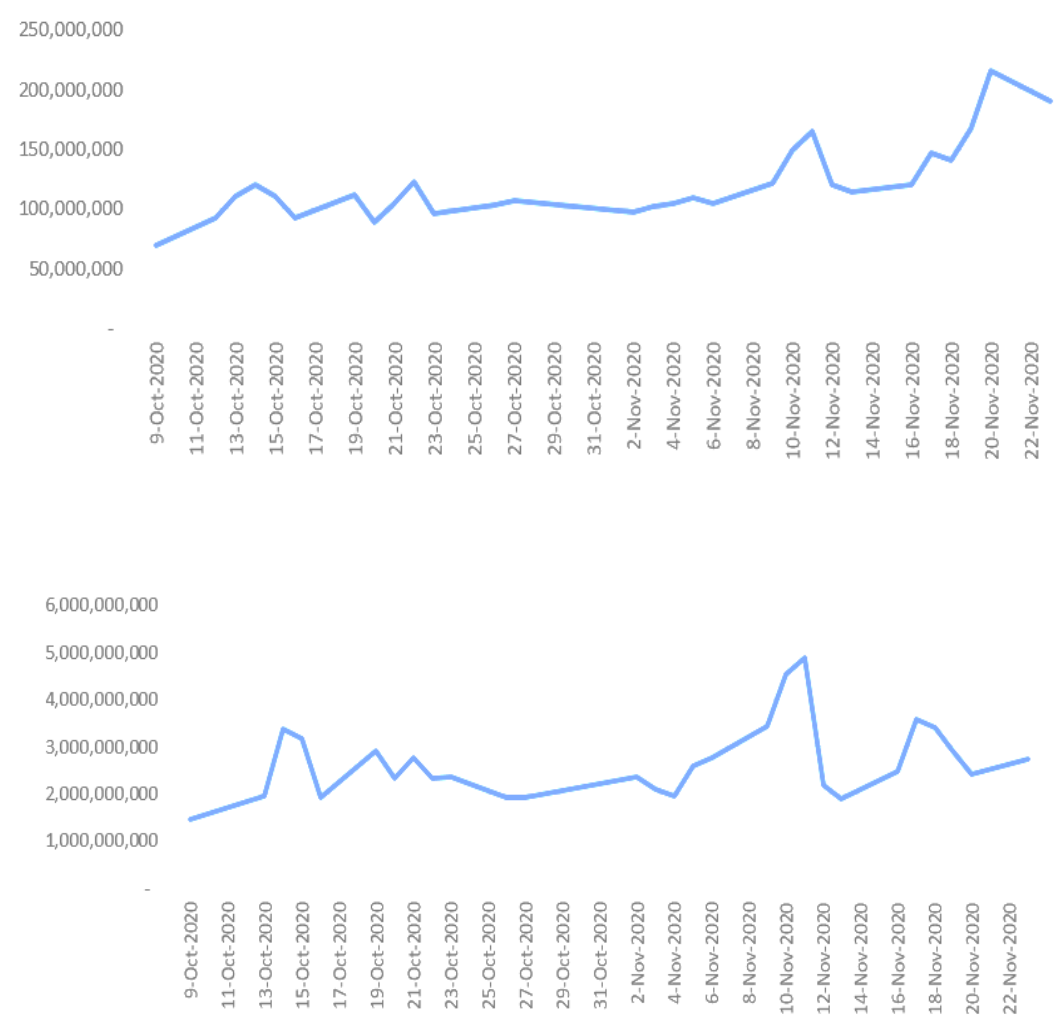

Gambar 1. Trading Volume Activity IHSG dan LQ45 di 15 Hari Periode Pengamatan

Sumber : idx.co.id dan yahoo.finance

Berdasarkan penjelasan fenomena di atas, penelitian ini dilakukan dengan tujuan untuk mengetahui apakah peristiwa politik internasional dapat mempengaruhi imbal hasil tak normal serta trading volume activity pada LQ45 tahun 2020. Penelitian ini menggunakan metode single index model perhitungan abnormal return dengan menghitung return saham pada tiga puluh hari sebelum peristiwa berbeda dengan penelitian sebelumnya yang menyamakan return saham pada tiga puluh hari sehingga tidak dilakukan perhitungan mendalam.

\section{KAJIAN LITERATUR DAN PENGEMBANGAN HIPOTESIS}

Studi peristiwa merupakan pengembangan dari teori Fama (1970) yang memiliki konsep dasar bahwa suatu pasar (pasar modal dan pasar uang) dapat dikatakan efisien apabila tidak ada seorang pun baik institusional maupun ritel dapat mempeorleh imbal hasil tak normal, setelah disesuaikan dengan resiko, dengan menggunakan strategi perdanganan yang ada. Menurut Fahmi (2015) mengungkapkan bahwa hipotesis pasar efisien merupakan cerminan harga sekuritas atas segala informasi dan ramalan untuk waktu yang akan datang untuk peroleh keuntungan dalam pasar modal.

Menurut Jogiyanto (2015) abnormal return (imbal hasil tak normal) merupakan kelebihan atas pengembalian atau imbal hasil yang benar terjadi pada pengembalian normal. Anggraeni dkk (2021) mengemumakakan bahwa imbal hasil tak normal merupakan salah satu variabel untuk menguji kemampuan pasar, dan munculnya suatu abnormal return atau return tak normal biasanya berada pada sekitar berita atas suatu fenomena dan fenomena tersebut bisa datang dari isu ekonomi maupun nonekonomi. Sementara itu menurut Triono dkk. (2021) trading volume transaksi saham adalah jumlah saham yang diperjualbelikan pada periode tertentu. Besaran volume transaksi berubah tergantung minat investor dalam melakukan suatu transaksi di pasar modal. Ifa (2020) mengemukakan bahwa nilai 
volume transaksi dapat berubah tergantung atas suatu peristwa yang terjadi baik dialam itu sendiri maupun di luar perusahaan itu sendiri. Pada perjalanannya, pasar modal Indonesia telah terdampak berbagai tantangan dalam lingkup ekonomi dan/atau non-ekonomi, seperti peristiwa poiltik, pemilu, stabilitas negara, unjuk kekuatan militer baik di dalam negeri maupun luar negeri. Diniar \& Kiryanto (2016) menyatakan bahwa kemenangan Joko Widodo pada pemilu 2014 membuat indeks LQ45 mengalami kenaikan.

Berkaitan dengan peristiwa politik Internasional, pasar modal Indonesia tak luput dari paparan atas peristiwa tersebut yang menyebabkan adanya abnormal return, berdasarkan catatan penelitian yang telah di publikasikan pasar modal Indonesia kerap bereaksi atas peristiwa yang terjadi di luar negeri. Silaban \& Sedana (2018) serta Kusumayanti \& Suarjaya (2018) sepakat menyatakan bahwa kemenangan Donald Trump dalam pemilihan presiden Amerika Serika tahun 2016 memberikan reaksi yang cukup signifikan pada pasar modal Indonesia di sekitar periode peristiwa. Menurut Jogiyanto (2015) abnormal return merupakan kelebihan atas pengembalian atau imbal hasil yang benar terjadi pada pengembalian normal. Anggraeni dkk (2021) mengemumakakan bahwa abnormal return merupakan salah satu alat untuk menguji kemampuan pasar, dan munculnya suatu abnormal return atau return tak normal biasanya berada pada sekitar berita atas suatu fenomena, dan fenomena tersebut bisa datang dari isu ekonomi maupun ekonomi. Pada perjalanan nya, pasar modal Indonesia telah terdampak berbagai tantangan baik di lingkungan ekonomi maupun non-ekonomi seperti, peristiwa poiltik, pemilu, stabilitas negara, unjuk kekuatan militer baik di dalam negeri maupun luar negeri. Diniar \& Kiryanto (2016) menyatakan bahwa kemenangan Joko Widodo pada pemilu 2014 membuat indeks LQ45 mengalami kenaikan. Peneliti lain yang menyatakan hal serupa yakni Sihotang \& Mekel (2015) meneliti hubungan peristiwa tersebut terhadap pasar modal Indonesia dan memberikan kesimpulan bahwa terdapat perbedaan yang cukup berdampak terhadap trading volume activity atas peristiwa politik tersebut. Sementara itu berkaitan dengan peristiwa politik Internasional, pasar modal Indonesia tak luput dari paparan atas peristiwa tersebut yang menyebabkan mengalami adanya abnormal return. Berdasarkan catatan penelitian yang telah dipublikasikan, pasar modal Indonesia kerap bereaksi atas peristiwa yang terjadi di luar negeri. Silaban \& Sedana (2018) serta Kusumayanti \& Suarjaya (2018) sepakat menyatakan bahwa kemeangan Donald Trump dalam pemilihan presiden Amerika Serikat tahun 2016 memberikan reaksi yang cukup signifikan pada pasar modal Indonesia di sekitar periode peristiwa. Walaupun demikian ada beberapa peneliti yang memiliki pendapat berbeda terkait peristiwa politik terhadap abnormal return, seperti Pratama (2015) \& Cahyani (2017) menyatakan bahwa peristiwa politik tidak terdapat pengaruh yang signifikan terhadap pasar modal. Pada trading volume activity, peneliti seperti Ivani (2019) dan Silaban \& Sedana (2018) menyatakan hasil yang berbeda tentang efek situasi politik terhadap pasar modal Indonesia khususunya pada trading volume activity berdasarkan uraian di atas, dibentuk hipotesis sebagai berikut.

$\mathrm{H}_{1}$ : terdapat reaksi pada abnormal return yang signifikan di saham LQ45 pada hari sekitar peristiwa pengumuman Pemilihan Presiden Amerika Serikat tahun 2020.

$\mathrm{H}_{2}$ : terdapat perbedaan reaksi abnormal return sebelum dan sesudah peristiwa pengumuman Pemilihan Presiden Amerika Serikat tahun 2020 pada saham LQ45.

$\mathrm{H}_{3}$ : terdapat reaksi pada trading volume activity yang signifikan di saham LQ45 pada hari sekitar peristiwa pengumuman Pemilihan Presiden Amerika Serikat tahun 2020.

\section{METODE PENELITIAN}

Pendekatan yang dilakukan dalam penelitian ini adalah pendekatan kuantitatif dengan menguji signifikansi abnormal return dan trading volume activity yang ada serta membandingkan perbedaan abnormal return tujuh hari sebelum dan sesudah peristiwa pemilu AS tahun 2020 pada perusahaan yang 
masuk dalam LQ45 periode Agustus 2020-Januari 2021 di Bursa Efek Indonesia. Variabel yang diuji dalam penelitian ini adalah abonrmal return dan trading volume activity. Abnormal Return menurut (Hartono, 2017) adalah return yang didapatkan dari perhitungan return sesungguhnya dengan dikurangi oleh return ekspektasi. Pada penelitian ini, perhitungan abnormal return dimulai dari tujuh hari sebelum dan sesudah peristiwa pengumuman Hasil Pilpres Amerika Serikat tahun 2020. Trading volume activity menurut Ivani N. S. (2019) merupakan volume perdagangan yang dapat dilihat dengan menggunakan indikator aktivitas perdagangan dengan rumus sebagai berikut.

$$
T V A=\frac{\sum \text { saham } i \text { ditransaksikan pada waktu } t}{\sum \text { saham } i \text { beredar waktu } t}
$$

Teknik analisis data yang digunakan dalam penelitian ini mencari abnormal return dengan metode single index model, dan trading volume activity dengan rumus satu di atas. Untuk mengujinya menggunakan uji one sample t-test dan paired sample t-test bagi data yang terdistribusi normal dan untuk data tidak terdistribusi secara normal menggunakan uji wilcoxon one sample signed rank test.

\section{HASIL DAN PEMBAHASAN}

\section{Analisis Statistik Deskriptif}

Statistik deskriptif merupakan gambaran nilai minimum, nilai maksimum, nilai rata-rata, dan nilai standar deviasi dari masing-masing varibel data yang akan diolah. Analisis statistik deskriptif dalam penelitian ini terbagi menjadi dua, yakni analisis deskriptif abnormal return yang dilihat dari rata-rata abnormal return dan analisis deskriptif trading volume activity yang dilihat dari rata-rata trading volume activity. Berikut hasil analisis statistic deskriptif dari average abnormal return selama lima belas hari periode penelitian yang terbagi menjadi tujuh hari sebelum dan tujuh hari sesudah peristiwa dan satu hari periode peristiwa terjadi, yakni peristiwa pengumuman hasil pemilihan Presiden AS tahun 2020.

Tabel 1. Deskriptive Statistics

\begin{tabular}{lrrrrr}
\hline & N & Minimum & Maximum & \multicolumn{1}{c}{ Mean } & Std. Deviation \\
\hline tmin7 & 45 & $-0,052$ & 0,048 & $-0,009$ & 0,020 \\
tmin6 & 45 & $-0,035$ & 0,037 & $-0,003$ & 0,013 \\
tmin5 & 45 & $-0,044$ & 0,056 & $-0,003$ & 0,020 \\
tmin4 & 45 & $-0,045$ & 0,109 & $-0,000$ & 0,024 \\
tmin3 & 45 & $-0,050$ & 0,032 & $-0,006$ & 0,019 \\
tmin2 & 45 & $-0,074$ & 0,067 & $-0,005$ & 0,026 \\
Tmin1 & 45 & $-0,050$ & 0,048 & 0,003 & 0,020 \\
Tnol & 45 & $-0,048$ & 0,079 & 0,003 & 0,023 \\
tplus1 & 45 & $-0,097$ & 0,102 & $-0,002$ & 0,037 \\
tplus2 & 45 & $-0,060$ & 0,068 & $-0,008$ & 0,030 \\
tplus3 & 45 & $-0,031$ & 0,026 & 0,000 & 0,015 \\
tplus4 & 45 & $-0,022$ & 0,051 & 0,002 & 0,016 \\
tplus5 & 45 & $-0,031$ & 0,071 & 0,009 & 0,023 \\
tplus6 & 45 & $-0,035$ & 0,052 & 0,001 & 0,021 \\
tplus7 & 45 & $-0,043$ & 0,065 & $-0,004$ & 0,019 \\
AARSBLM & 45 & $-0,023$ & 0,011 & $-0,003$ & 0,007 \\
AARSSDH & 45 & $-0,026$ & 0,018 & $-0,000$ & 0,009 \\
\hline
\end{tabular}


Pada tabel di atas diketahui bahwa saham yang memiliki perolehan abnormal return tertinggi ada di T-4 dan T+1, yang mana lebih detail dapat dilihat saham tersebut ialah SRIL di T-4 serta BTPS di T+1. Penyebab terjadinya peningkatan kinerja saham SRIL (PT Sri Rejeki Isman Tbk) pada T-4 disebabkan karena adanya sentimen positif atas perpanjangan fasilitas GSP (Generalized System of Preferences) dari Amerika Serikat, yakni fasilitas yang membebaskan bea masuk bagi barang impor dari Indonesia. SRIL yang merupakan produsen tekstil menjadi sentimen positif baginya untuk mendulang untung. Berdasarkan laporan keuangan yang diterbitkan di Indonesia Stock Exchange (idx.co.id), SRIL membukukan pendapatan bersih US\$907,09 juta, yang mana 9,170\% dari angka tersebut merupakan penjualan ke kawasan AS dan Amerika Latin. Sementara untuk kenaikan BTPS pada T+1 terjadi karena adanya aksi pembelian besar-besaran saham yang dilakukan oleh asing karena lima hari sebelumnya, asing melakukan jual Rp6 mililar dengan transaksi sebesar Rp40,2 miliar menyebabkan saham ambles sebesar 3,390\% dan investor berspekulasi atas saham yang murah tersebut dengan melakukan aksi buy secara besar-besaran menyebabkan saham tinggi pada T+1. Artinya, pada saham BTPS (Bank BTPN Syariah Tbk), kenaikan terjadi kemungkinan tidak terkait dengan peristiwa politik tetapi karena spekulan semata oleh investor yang melihat masih undervalue saham tersebut pada lima hari sebelumnya.

\section{Analisis Abnormal Return}

Perhitungan abnormal return yaitu dengan cara mengurangi return sesungguhnya dengan return yang diharapkan (expected return). Metode yang digunakan untuk melakukan perhitungan abnormal return pada penelitian ini adalah dengan meregresikan antara Rit dengan Rmt untuk mendapatkan alpha $=\alpha$ dan Beta $=\beta$ yang digunakan untuk mendapatkan return ekspektasi (expected return) yang digunakan untuk mencari abnormal return-nya yang dikenal dengan single index model atau market model. Berikut merupakan hasil regresi yang dilakukan, yaitu dengan cara meregresikan return per-saham di periode estimasi dengan return pasar di periode estimasi.

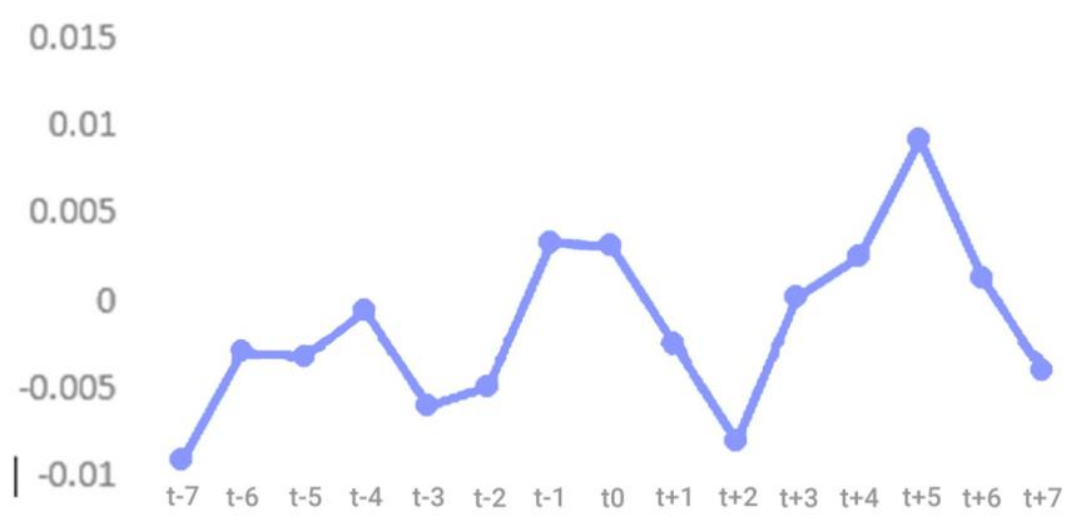

\section{Gambar 1. Rata-rata abnormal return LQ45 tahun 2020}

Terlihat pada grafik di atas bahwa perolehan average abnormal return tertinggi berada pada hari ke-5 setelah pengumuman berlangsung, yakni sebesar 0,009 , sedangkan nilai terendah berada pada hari ke-7 sebelum pengumuman pilpres AS tahun 2020 sebesar -0,009. Hal ini menunjukkan indikasi bahwa pasar modal pada khususnya saham yang tergabung dalam LQ45 bereaksi atas adanya peristiwa tersebut jika dilihat dari pola pergerakan dari average abnormal return dari 45 perusahaan selama lima belas hari periode pengamatan. Rata-rata abnormal return merupakan nilai rata-rata dari imbal hasil tak 
normal masing-masing perusahaan pada setiap harinya selama lima belas hari berturut turut (dalam penelitian ini menggunakan waktu pengamatan sebanyak lima belas hari).

\section{Analisis Trading Volume Activity}

Data dari hasil aktivitas volume perdagangan ini digunakan untuk mengetahui signifikansi atas menaiknya perolehan tersebut. Pada tahap penelitian ini Trading Volume Activity didapatkan dari hasil perhitungan jumlah saham yang diperdagangkan setiap harinya dibagi jumlah saham yang beredar.

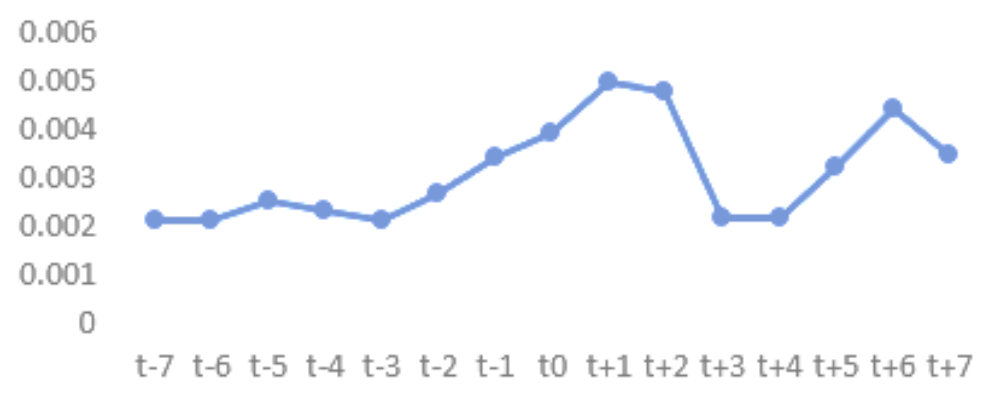

Gambar 2. Rata-Rata Aktivitas Volume Perdagangan LQ45 tahun 2020

Terlihat pada grafik di atas bahwa perolehan average trading volume tertinggi berada pada $\mathrm{T}+1$ atau hari ke-1 setelah pengumuman terjadi, yakni sebesar 0,005 sedangkan nilai terendah terjadi pada hari ke- 6 sebelum pengumuman terjadi dengan nilai sebesar 0,002 . Hal ini menunjukkan indikasi bahwa pasar modal pada khususnya saham dalam indeks LQ45 bereaksi atas adanya peristiwa tersebut jika dilihat dari pola pergerakan atas aktivitas volume perdagangan rata-rata (ATVA) selama lima belas hari waktu periode pengamatan.

\section{Uji Parsial t}

Pada Tabel 2 disajikan hasil One-sample t-test dan One-sample Wilcoxon Signed Rank Test terlihat signifikansi abnormal return pada setiap hari dari lima belas hari periode jendela atau pengamatan. Begitu pun pada Tabel 2 yang merupakan hasil One-sample Wilcoxon Signed Rank Test untuk melihat signifikansi trading volume activity pada setiap hari dari lima belas hari periode jendela atau pengamatan. 
Tabel 2. Hasil Uji Signifikansi Abnormal Return dan Trading Volume Activity

\begin{tabular}{llllll}
\hline \multicolumn{1}{c}{ Data } & Sig. & \multicolumn{1}{c}{ Kesimpulan } & \multicolumn{1}{c}{ Data } & Sig. & \multicolumn{1}{c}{ Kesimpulan } \\
\hline tmin7 & 0,004 & AR signifikan & tmin7 & 0 & TVA signifikan \\
tmin6 & 0,140 & AR Tidak signifikan & tmin6 & 0 & TVA signifikan \\
tmin5 & 0,287 & AR Tidak signifikan & tmin5 & 0 & TVA signifikan \\
tmin4 & 0,340 & AR Tidak signifikan & tmin4 & 0 & TVA signifikan \\
tmin3 & 0,037 & AR signifikan & tmin3 & 0 & TVA signifikan \\
tmin2 & 0,217 & AR Tidak signifikan & tmin2 & 0 & TVA signifikan \\
tmin1 & 0,279 & AR Tidak signifikan & tmin1 & 0 & TVA signifikan \\
Tnol & 0,362 & AR Tidak signifikan & Tnol & 0 & TVA signifikan \\
tplus1 & 0,673 & AR Tidak signifikan & tplus1 & 0 & TVA signifikan \\
tplus2 & 0,083 & AR Tidak signifikan & tplus2 & 0 & TVA signifikan \\
tplus3 & 0,943 & AR Tidak signifikan & tplus3 & 0 & TVA signifikan \\
tplus4 & 0,295 & AR Tidak signifikan & tplus4 & 0 & TVA signifikan \\
tplus5 & 0,012 & AR signifikan & tplus5 & 0 & TVA signifikan \\
tplus6 & 0,689 & AR Tidak signifikan & tplus6 & 0 & TVA signifikan \\
tplus7 & 0,173 & AR Tidak signifikan & tplus7 & 0 & TVA signifikan \\
\hline
\end{tabular}

Dapat ditarik kesimpulan bahwa dalam lima belas hari periode pengamatan hanya tiga hari yang terdapat abnormal return signifikan, dan ternyata secara keseluruhan abnormal return tidak bereaksi atas adanya peristiwa politik internasional. Pasar dianggap telah efisien karena segala informasi yang ada di publik telah diserap oleh pasar sedangkan pada trading volume activity berdasarkan hasil pengujian pada Tabel 2, menggunakan alat One Sample Wilcoxon Signed Rank Test Trading Volume Activity saat pengumuman pilpres AS 2020 untuk T-7 sampai T+7 menunjukan hasil signifikansi dengan nilai sama yakni 0,000 . dapat diartikan terdapat nilai signifikansi statistic lebih kecil dari tingkat signifikan dengan nilai $0,050(0,000<0,050)$. sehingga dapat dikatakan bahwa $\mathrm{T}-7$ sampai $\mathrm{T}+7$ sepakat terdapat trading volume activity yang signifikan. maknanya aktivitas perdagangan investor pada bursa saham Indonesia bereaksi atas adanya pengumuman hasil pemilihan presiden AS 2020 ditujukan dengan signifikansi TVA selama lima belas hari periode pengamatan.

\section{Uji Beda t}

Uji Beda t-test akan dilakukan tujuannya untuk mengetahui pengaruh antara dua variabel yang saling berhubungan apakah terjadi perbedaan antar variabel yang digunakan. Berikut ini merupakan hasil olah paired Sample t-test.

Tabel 3. Uji Beda T Pada Abnormal Return

\begin{tabular}{|c|c|c|c|c|c|c|c|c|c|}
\hline & & Mean & $\begin{array}{c}\text { Std. } \\
\text { Deviasi }\end{array}$ & $\begin{array}{l}\text { Std Error } \\
\text { Mean }\end{array}$ & Lower & Upper & $t$ & Df & $\begin{array}{c}\text { Sig } \\
\text { (2tailed) }\end{array}$ \\
\hline Pair & $\begin{array}{l}\text { AARS } \\
\text { BLM - } \\
\text { AARS } \\
\text { SDH }\end{array}$ & $-0,003$ & 0,009 & 0,001 & $-0,006$ & $-0,000$ & $-2,229$ & 44 & 0,031 \\
\hline
\end{tabular}

Dari hasil uji beda diketahui bahwa nilai sig. (2-tailed) adalah sebesar 0,031 < probabilitas 0,050, maka dapat dikatakan ada perbedaan antara average abnormal return sebelum dan sesudah peristiwa 
Jidan Apriyanto: Reaksi Pasar Modal ...

pilpres AS tahun 2020 dibuktikan dengan hasil signifikansi uji beda di atas. Dan sesuai dengan hipotesis penelitian ini Terdapat perbedaan reaksi abnormal return sebelum dan sesudah peristiwa pengumuman Pemilihan Presiden Amerika Serikat tahun 2020 pada saham LQ45.

\section{Pembahasan}

\section{Signifikansi Abnormal Return}

Dalam penelitian ini dapat dikatakan bahwa LQ45 bereaksi hanya dalam tiga hari periode pengamatan sisanya, yakni menurut uji statistik sebanyak dua belas hari periode pengamatan tidak terdapat abnormal return signifikan. Pengumuman pemilihan presiden AS tahun 2020 memang menjadi sorotan hampir seantero dunia, bagaimana tidak selama lima belas hari periode pengamatan secara kasar memang rata-rata abnormal return IHSG dan LQ45 sama-sama mengalami pola kenaikan yang cukup mirip jika dilihat secara kasar nya saja dan mengalami kenaikan yang cukup agresif, tetapi menurut hasil uji statistik yang telah dilakukan hanya tiga hari saja yang ternyata benar-benar mengalami imbal hasil tak normal yang kuat, yakni hari ke-7 dan ke-3 sebelum peristiwa serta hari ke-5 setelah peristiwa selebihnya yakni dua belas hari dari lima belas hari periode pengamatan tidak terjadi abnormal return yang signifikan.

Diperkuat oleh penelitian yang mendapatkan hasil serupa dengan penelitian ini yaitu oleh Nurvita (2019) menyatakan bahwa memang terdapat kandungan informasi berupa pelaksaaan pilpres Indonesia 2019 yang membuat saham hari ke-9 dan ke-5 berekasi dan sisanya selama tiga puluh hari sebelum dan sesudah tidak timbul abnormal return yang signifikan. Hasil pengujian abnormal return yang telah dilakukan dapat disimpulkan bahwa ternyata dalam lima belas hari periode pengamatan perihal terjadinya suatu peristiwa tidak mempengaruhi pasar modal Indonesia untuk 45 perusahaan yang terdaftar dalam LQ45 tahun 2020 jika dilihat dari aspek abnormal return nya, dimana dalam lima belas hari waktu pengamatan menurut statistic hanya tiga hari yang memiliki abnormal return yang kuat yakni hari ke-7 dan ke-3 sebelum peristiwa terjadi serta hari ke-5 setelah peristiwa tersebut terjadi.

\section{Perbedaan Abnormal Return LQ45 Sebelum Pengumuman dan Sesudah Pengumuman Pemilihan Presiden AS Tahun 2020}

Dapat dikatakan dalam penelitian ini indeks LQ45 mengalami reaksi atas peristiwa pengumuman pilpres AS tahun 2020 dan reaksi yang cukup menguntungkan investor karena pasar bereaksi positif atau mengalami kenaikan dibandingkan sebelum peristiwa itu terjadi. Hasil pengujian ini seusai dengan penelitian Lehkonen \& Heimonen (2015), Oeghler dkk. (2016), Wisniewski (2016), Liu \& Wei (2017), Yulita (2017), Katti (2018), Murdifi dkk. (2018), Nisar \& Yeung (2018), Ivani (2019), Hillier \& Loncan (2019), Nurvita (2019), Ahmed dkk. (2020), Eldomiaty dkk. (2020) yang menyatakan bahwa peristiwa politik menimbulkan adanya beda harga saham antara sebelum dan sesudah peristiwa terjadi.

Namun menyikapi banyak nya hasil yang tidak signifikan, peneliti berpendapat bahwa pasar saham Indonesia telah efisien dimana pasar telah menyerap informasi yang ada, yang didukung oleh teori Fama (1991) di mana investor tidak akan mendapat abnormal return pada pasar modal yang telah efisien, yang terlihat dari hasil uji menyatakan hanya satu hari saja setelah pengumuman pilpres yang mengalami adanya abnormal return dari tujuh hari periode pengamatan untuk setelah pengumuman, dan peneliti berpendapat bahwa investor Indonesia pada umumnya dan indeks LQ45 khususnya tidak memiliki harapan lebih atas terpilihnya Joe Biden sebagai presiden AS periode tersebuit, maksudnya adalah investor bersyukur bahwa bukan Donald Trump yang terpilih, tetapi terpilihnya Joe Biden sebagai presiden AS tidak menjadi harapan yang tinggi atas kemajuan AS kedepannya, jika dilihat dari janji kampanye yang dilontarkan, Joe Biden cenderung main aman dengan tidak mengusik pihak manapun, dan cenderung mengambil hati pejuang aktivis hak asasi manusia yang mana memang 
menjadi masalah serius ketika Donald Trump menjabat sebagai presiden AS periode sebelumnya (Paranes \& Easley, 2020).

\section{Signifikansi Trading Volume Activity (TVA)}

Berbeda dengan Abnormal Return yang mana dari lima belas hari periode pengamatan, hanya tiga hari yang menujukkan hasil signfikan, untuk trading volume activity atas indeks LQ45 tahun 2020 bagi 45 perusahaan tersebut mengalami hasil signifikan di semua hari pengamatan. Hasil statistik One Sample Wilcoxon Signed Rank Test mengatakan bahwa telah terjadi aktivitas perdagangan yang signifikan dalam lima belas hari tersebut, didukung oleh penelitian dari Silaban (2018) yang menyatakan bahwa peristiwa politik AS tahun 2016 membuat perbedaan signifikan atas TVA bursa Indonesia khususnya LQ45 pada periode tersebut, sedangkan abnormal return tidak ada perbedaan. Hal ini menjadi menarik ketika terjadi perdagangan saham yang tinggi tetapi tidak menghasilkan abnormal return yang signifikan jika kita mengacu pada hasil uji abnormal return pada penelitian ini.

Untuk menyikapi hal ini peneliti memiliki asumsi atau pendapat tentang peristiwa ini. Dalam perhitungan TVA membutuhkan dua elemen utama, yakni data jumlah saham yang diperjual belikan pada hari terkait dan data jumlah saham yang beredar pada perusahaan terkait. Yang mana menghasilkan nilai yang kita kenal dengan TVA. Jika dilihat secara sekilas grafik ATVA dan AAR memiliki pola yang sedikit mirip namun tidak identik. Artinya, ATVA dan AAR memiliki keterkaitan satu sama lain. Namun, di satu sisi, jika kita lihat grafik ATVA pada Gambar 2 yang mengalami kenaikan tertinggi atau terjadi aktivitas tertinggi perdagangan saham, yakni berada pada hari ke-1 dan ke-2 setelah pengumuman. Jika kita mengacu pada hasil uji statistik untuk AAR pada hari ke-1 dan ke-2 tidak mengalami abnormal return yang signifikan, kejadian unik yang menarik untuk dibahas. Asumsi peneliti adalah memang terjadi peningkatan volume perdagangan yang tinggi pada hari tersebut tetapi investor hanya melakukan aktivitas perdagangan yang bergerak ditempat. Investor melakukan aksi pimpong saham yang mencoba mengambil untung atas peristiwa pengumuman pilpres AS tahun 2020 tersebut yang ditujukan bahwa pada $\mathrm{T}+1$ dan $\mathrm{T}+2$ tidak mengalami abnormal return yang signifikan.

Signifikannya hasil statistik dari trading volume activity tidak terlepas dari banyaknya media masa di dunia yang mempublikasi dan menyoroti tentang pilpres Amerika Serikat 2020, terlebih negara tersebut sering menjadi sorotan karena kontroversi yang kerap dilakukan oleh pemimpin sebelumnya yakni Donald Trump. Media sosial seperti Twitter pun tak urung menjadi pengaruh mengapa ada TVA yang signifikan, seperti yang ada pada penelitian Nisar \& Yeung (2018) mengatakan bahwa Twitter menjadi alat untuk meramal pergerakan dari stock market ketika ada peristiwa politik. Hal ini terjadi karena masyarakat berupaya mengemukakan opininya di tengah terjadinya suatu kejadian. Ini menjadi penyebab bagaimana investor mengambil sikap karena ternyata kejadian tersebut memang bukan kejadian kecil ditujukan dari masifnya publikasi yang beredar luas di masyarakat. Investor mencoba memanfaatkan moment tersebut untuk mencari return setinggi-tinggi nya sehingga menimbulkan TVA yang cukup tinggi disekitar peristiwa kejadian. Pada saat kampanye berlangsung saja bisa dikatakan bahwa media masa menyoroti ajang akbar Amerika Serikat tersebut. Hal ini diperkuat dengan disuarakannya kampanye yang mewakili rakyat Amerika oleh Joe Biden, sedangkan lawannya masih tetap idealism yang tinggi dengan kontroversinya.

\section{KESIMPULAN}

Berdasarkan hasil pembahasan disimpulkan bahwa tidak terdapat abnormal return yang signifikan pada perusahaan LQ45 tahun 2020 disekitar periode peristiwa pengumuman Pilpres AS tahun 2020. Terdapat perbedaan abnormal return yang signifikan antara sebelum pengumuman pilpres AS tahun 2020 dan sesudah pengumuman pilpres AS tahun 2020. Terdapat trading volume activity yang signifikan pada 
perusahaan LQ45 tahun 2020 disekitar periode peristiwa pengumuman pilpres AS tahun 2020. Penelitan selanjutnya dapat mempergunakan variabel diluar penelitian ini yang berpengaruh seperti kondisi makro, mata uang, suku bunga dan hal serupa lainnya karena hal tersebut erat kaitannya dengan peristiwa politik tetapi tidak eksplisit. Selain itu, jika menggunakan latar peristiwa politik AS dapat menjelaskan detail saham yang sangat sensitif terhadap perkembangan informasi dari Amerika Serikat. Hal lainnya dapat menggunakan peristiwa luar negeri lainnya tidak hanya terfokus pada Amerika Serikat, seperti Eropa (UK), China, dan lainnya. Untuk penelitian berikutnya disarankan menggunakan metode, seperti Capital Asset Pricing Model (CAPM), ataupun market adjusted model untuk mencari abnormal return. Bisa juga memperbanyak sampel yang digunakan, jendela lebih diperluas seperti tiga puluh hari, enam puluh hari, atau sertatus hari sebelum dan sesudah, untuk memperkuat analisis pada penelitian berikutnya.

Bagi investor, ketika menginvestasikan dananya di pasar modal saham, harus mempertimbangkan dengan cermat dan membuat keputusan investasi ketika terjadi peristiwaperistiwa yang dapat mempengaruhi pergerakan saham. Terlebih pada penelitian ini digunakan LQ45 yang kita ketahui merupakan saham yang paling sering diperdagankan oleh Investor. Berdasarkan penelitian yang telah dilakukan ini pasar saham Indonesia bereaksi atas peristiwa politik internasional yang terlihat dari perbedaan abnormal return dan aktivitas perdagangan saham sebelum dan sesudah terjadinya peristiwa, namun jika diuji secara individual hanya tiga hari abnormal return bagi pasar modal berekasi pada peristiwa politik.

\section{DAFTAR PUSTAKA}

Ahmed, F., Bahoo, S., Aslam, S., \& Qureshi, M. A. (2020). Meta-analysis on American presidential election - 2016 and american stock market. Estudios de Economia Aplicada, 38(1). https://doi.org/10.25115/eae.v38i1.2948

Anggraeni, A. P., Handini, D. P., \& Wulandari, W. (2021). Analisis Komparatif Abnormal Return Dan Trading Volume Activity Pt Telkom Indonesia (Event Study Pandemi). Proceeding Conference on Economic and Business Innovation, 1(1), 328-334.

Cahyani, A. D. (2017). Pengujian Efisiensi Pasar Bentuk Setengah Kuat Pada Saham-saham Yang Terdaftar di III (Study Event pada Pengumuman Vonis Ahok 9 Mei 2017). UIN Sunan Kalijaga.

Diniar, A. H., \& Kiryanto, K. (2016). Analisis Dampak Pemilu Presiden Jokowi Terhadap Return Saham (Studi Kasus Saham LQ-45 di Bursa Efek Indonesia). Jurnal Akuntansi Indonesia, 4(2), 97-108. https://doi.org/10.30659/jai.4.2.97-108

Eldomiaty, T. I., Anwar, M., Magdy, N., \& Hakam, M. N. (2020). Robust Examination Of Political Structural Breaks And Abnormal Stock Returns In Egypt. Future Business Journal, 6(1). https://doi.org/10.1186/s43093-020-00014-z

Fahmi, I. (2015). Manajemen Investasi: Teori dan Soal Jawab, Edisi 2. Jakarta: Salemba Empat.

Fama, E. F. (1970). Efficient Capital Markets: A Review of Theory and Empirical Work. The Journal of Finance, 25(2), 383-417. https://doi.org/10.2307/2325486

Fama, E. F. (1991). Efficient Capital Markets: II. The Journal of Finance, 46(5), 1575-1617. https://doi.org/10.2307/2328565

Hartono, J. (2017). Teori Portofolio dan Analisis Investasi: Edisi Kesebelas, Yogyakarta: BPFE - Yogyakarta. Hillier, D., \& Loncan, T. (2019). Political uncertainty and Stock returns: Evidence from the Brazilian Political Crisis. Pacific Basin Finance Journal, 54, 1-12. https://doi.org/10.1016/j.pacfin.2019.01.004

Ivani, N. S. (2019). Pengaruh Pemilu Presiden Indonesia Tahun 2019 Terhadap Abnormal Return Dan Trading Volume Activity Studi Pada Saham LQ45. Jurnal Al-Qardh, 4(1), 1-14.

Jogiyanto, H. 2015. Teori Portofolio dan Analisis Investasi. Edisi 10 Cetakan 1. Yogyakarta: BPFE. 
Katti, S. W. B. (2018). Pengaruh Peristiwa Politik (Pemilu Presiden dan Pengumuman Susunan Kabinet) Terhadap Saham Sektor Industri Di Bursa Efek Indonesia. Capital: Jurnal Ekonomi Dan Manajemen, 1(2), 125-134. https://doi.org/10.25273/capital.v1i2.2319

Kusumayanti, K. R., \& Suarjaya, A. A. G. (2018). Reaksi Pasar Modal Indonesia Terhadap Pengumuman Kemenangan Donald Trump Dalam Pilpres Amerika Serikat 2016. E-Jurnal Manajemen Universitas Udayana, 7(4), 1713-1741. https://doi.org/10.24843/ejmunud.2018.v07.i04.p01

Lehkonen, H., \& Heimonen, K. (2015). Democracy, political risks and stock market performance. Journal of International Money and Finance, 59, 77-99. https://doi.org/10.1016/j.jimonfin.2015.06.002

Liu, L. X., Shu, H., \& Wei, K. C. J. (2017). The Impacts Of Political Uncertainty On Asset Prices: Evidence From The Bo Scandal In China. Journal of Financial Economics, 125(2), 286-310. https://doi.org/10.1016/j.jfineco.2017.05.011

Murdifi, Hidayati, N., \& Junaidi. (2018). Efek Peristiwa Politik Terhadap Kinerja Pasar Modal Indonesia (Even Study Pada Vonis Yang Diberikan Kepada Basuki Tjahaja Purnama). Jurnal Ilmiah Riset Akuntansi, 7(6), 50-61.

Nailiu, B. A. (2014). Pengaruh Pengumuman Pencapresan Jokowi 2014 Di Bursa Efek Indonesia (Event Study: "Jokowi Effect" Pada Saham LQ45). (Unpublished Disertation). Universitas Atma Jaya Yogyakarta.

Nisar, T. M., \& Yeung, M. (2018). Twitter As A Tool For Forecasting Stock Market Movements: A ShortWindow Event Study. Journal of Finance and Data Science, 4(2), 101-119. https://doi.org/10.1016/j.jfds.2017.11.002

Nurmasari, I. (2020) Dampak Covid-19 Terhadap Perubahan Harga Saham dan Volume Transaksi. Jurnal Sekuritas, 3(3), 230-236. http://dx.doi.org/10.32493/skt.v3i3.5022.

Nurvita, T. (2020). Pengaruh Hasil Pengumuman Pemilihan Presiden 2019 Terhadap Harga Saham Di Bursa Efek Indonesia. ESENSI: Jurnal Manajemen Bisnis, 22(3), 337-347.

Önder, Z., \& Şimga-Mugan, C. (2006). How Do Political and Economic News Affect Emerging Markets? Evidence from Argentina and Turkey. Emerging Markets Finance and Trade, 42(4). https://doi.org/10.2753/ree1540-496×420403

Parnes, A., \& Easley, J. (2020, September 14). Democrats Worry Biden Playing It Too Safe. The Hill. https://thehill.com/homenews/campaign/516394-democrats-worry-biden-playing-it-toosafe?rl=1

Pratama, I. G. B., Sinarwati, N. K., \& Dharmawan, N. A. S. (2015). Reaksi Pasar Modal Indonesia Terhadap Peristiwa Politik (Event Study pada Peristiwa Pelantikan Joko Widodo Sebagai Presiden Republik Indonesia Ke-7). Jurnal Akuntansi Universitas Pendidikan Ganesha, 3(1). http://dx.doi.org/10.23887/jimat.v3i1.4754

Rahayu, C. W. E. (2007). Reaksi Pasar Modal Terhadap Pengumuman Perombakan (Reshuffle) Terbatas Kabinet Indonesia Bersatu; Studi Empiris Pada Perusahaan Perusahaan yang Terdaftar di Bursa Efek Jakarta (BEJ). Sinergi, 9(2), 129-142. https://doi.org/10.20885/sinergi.vol9.iss2.art3

Sidik, S. (2020, November 8). Simak! Saham-Saham yang Berpeluang Cuan Usai Joe Biden Menang. CNBC Indonesia. https://www.cnbcindonesia.com/market/20201108192752-17-200228/simak-sahamsaham-yang-berpeluang-cuan-usai-joe-biden-menang

Sihotang, E. M., \& Mekel, P. A. (2015). Reaksi Pasar Modal Terhadap Pemilihan Umum Presiden Tanggal 9 Juli 2014 Di Indonesia. Jurnal EMBA, 3(1), 951-960.

Silaban, D. P., \& Sedana, I. P. (2019). Reaksi Pasar Modal Indonesia Terhadap Kemenangan Donald Trump Pada Pilpres 2016 Di Amerika Serikat. Jurnal Buletin Studi Ekonomi, 23(1), 92-107.

Triono, B., Hendrayanti, S., Fauziyanti, W., \& Estuti, E. P. (2021). Comparative Analysis Of Trading Volume Activity During Covid-19. Jurnal STIE Semarang, 13(1), 39-50. 
Trisnawati, F. (2011). Pengaruh Peristiwa Politik terhadap Perubahan Harga Saham. Jurnal Pendidikan dan Bisnis, 3(3), 528-535.

Wisniewski, T. P. (2016). Is There A Link Between Politics And Stock Returns? A Literature Survey. International Review of Financial Analysis, 47, 15-23. https://doi.org/10.1016/j.irfa.2016.06.015

Yulita, I. K. (2017). Reaksi Pasar Modal Terhadap Pengumuman Keputusan Investasi Raja Salman di Indonesia. Jurnal Penelitian, 21(1), 95-106. 